\title{
Path Analysis and Theory of Planned Behavior on Using PAP SMEAR as Early Detection of Cervical Cancer in Sewon I Community Health Center, Bantul, Yogyakarta, Indonesia
}

\author{
Fatimah Dewi Anggraeni'), Bhisma Murti²), Ruben Dharmawan²) \\ 1) School of Public Health, Graduate Program, Sebelas Maret University, Surakarta \\ 2) Faculty of Madicine, Sebelas Maret University, Surakarta
}

\begin{abstract}
Background: Cervical cancer patients per hour has increased by 2.5 people. Women died because of cervical cancer are 1.1 per hours. Indonesia is the second country after Tiongkok with the largest number incidence of cancer. Pap smear is one of the screening programs to reduce the numbers of cervical cancer genesis. Moreover in Indonesia, the rates of screening Pap smear less than 5\%. This study aimed to investigate path analyze of using pap smear with as early detection of cervical cancer by planned theory of behavior in women in Sewon 1 Public Health Center, Bantul.

Subjects and Method: This was an observational analytic study with the direction cross sectional design. A total sample of 96 women with comprised 32 cases and 64 control with fixed-disease sampling method. Data analysis used path analysis.

Results: The results show there is influence between intentions and screening Pap smear $(\mathrm{p}=<0.000)$, perceived behavioral control with Pap smear test $(\mathrm{p}=0.010)$. An indirectly interaction with the screening Pap smear through intention on attitudes $(\mathrm{p}=<0.001)$, subjective norms $(\mathrm{p}=0.036)$, and control behavior perceptions $(\mathrm{p}=0.034)$.

Conclusion: from this study there are interactions directly and indirectly the uses of screening Pap smear based on planned of behavior theory.
\end{abstract}

Keywords: Planned of behavior theory, screening pap smear

Correspondence:

Fatimah Dewi Anggraeni. School of Public Health, Graduate Program, Sebelas Maret University, Surakarta.

\section{BACKGROUND}

SDGs aims to promoting good health with a target to be achieved are to reduce one-third of deaths from non-communicable diseases. Cervical cancer is a disease that is not contagious (MoH, 2015). Cervical cancer is the second most frequent cancer occurring throughout the world. In 2012, there were 528,000 new cervical cancer cases are diagnosed around the world and $85 \%$ occured in less developed regions.

Cervical cancer caused 266,0000 women die from cervical cancer each year (WHO,
2014). Based on data from the Ministry of Health in 2015, the average hourly number of patients with cervical cancer increased 2.5 people and 1.1 women die from cervical cancer. D.I.Y (Yogyakarta) had the highest prevalence cancer that is equal to $1.5 \%$ by the number of the patients as much as 2,703 cases (Center for Data and Information Ministry of Health, 2015).

Screening is one way to prevent cervical cancer (Directorate of Non-Communicable Disease Prevention, 2009). The high mortality rate from cervical cancer globally 
Journal of Health Promotion and Behavior (2016), 1(1): 1-8

https://doi.org/10.26911/thejhpb.2016.01.01.01

(52\%) can be reduced by screening programs and effective treatment (WHO, 2014). Low coverage of cervical cancer detection caused developing cervical cancer. Early detection program in Indonesia is still less than $5 \%$ (Samasi, 2010).

Planned behavior theory is a theory in which the action/ treatment of an individual based on the reason. The central factor of planned behavior theory is the intention/ the intention of the individual to perform the behavior. Planned behavior theory possessed three conceptual in formation of intentions: attitude toward the behavior, subjective norm, and perceived behavioral control (Ajzen, 1991).

Based on the data in Sewon 1 Public Health, there are 6,591 registered couples of childbearing age and 32 women (0.48\%) who did Pap smear in 2015. This study aims to examine the relationship direct and indirect use of Pap smear is based on planned behavior theory in women of childbearing age in Sewon 1 public health.

Planned behavior theory is a theory designed to predict and explain human behavior in certain context. It is an extension of the theory of reaction. The central factor is the intention of the individual to do that has been given (Ajzen, 1991). There are three major predictors affecting the intentions of individuals to perform a behavior, the attitude toward a behavior, subejective norm of behavior (subjective norm), and the perception of control behavior (perceived behavioral control) (Ajzen, 2005).

Pap smear is a method of screening tests for cervical cancer by cytological examination of smear cells taken from the cervix are examined by a technician cytological or physician pathologist to see changes in the cells that indicate inflammation, dysplasia or cancer (Control Directorate Non Communicable Disease, 2009).

\section{SUBJECTS AND METHOD}

This was an analytic observational study with cross sectional design. This study was conducted in Sewon 1 Public Health from April to May 2016. The sample was taken by fixed-sampling technique. Total comparable estimates of case and control groups can use the ratio of 1:2. The number of respondents was 96 women comprised 32 respondents who had had a pap smear and 64 women who did not do a pap smear.

Endogenous variables of this study are: Pap smears screening and intentions and exogenous variables: attitude (attitude toward the behavior), subjective norm, perceived behavioral control. Data collection using questionnaire with choice questions and answer that have been available in 5 scale. Data analysis used path analysis model of trimming.

\section{RESULTS}

Table 1 shows that of the 96 most research subjects aged $>35$ years (45.83\%), most do not work and just do housework (56.25\%), mostly educated past high school (50\%), most diverse Islam (94.79\%), mostly have two children (37.5\%), mostly married at the age of 20-35 years (85.42\%), and most of the research income above the minimum wage (55.21\%).

Characteristics of survey respondents can be seen as follows: 
Table 1. Characteristics of respondents

\begin{tabular}{|c|c|c|c|}
\hline Characteristic & Criteria & $\mathbf{n}$ & $\%$ \\
\hline \multirow[t]{3}{*}{ Age } & $<20$ year & 2 & 2.08 \\
\hline & $20-35$ year & 44 & 45.83 \\
\hline & $>35$ year & 50 & $\begin{array}{l}52.0 \\
8\end{array}$ \\
\hline \multirow[t]{5}{*}{ Occupation } & House wives & 54 & 56.25 \\
\hline & Labor & 9 & 9.38 \\
\hline & Entrepreneur & 10 & 10.42 \\
\hline & Private employee & 20 & $\begin{array}{l}20.8 \\
3\end{array}$ \\
\hline & Civil Servants & 3 & 3.13 \\
\hline \multirow[t]{6}{*}{ Education } & Elementary School & 8 & 8.33 \\
\hline & Junior high school & 12 & 12.50 \\
\hline & Senior high school & 48 & $\begin{array}{l}50.0 \\
0\end{array}$ \\
\hline & Diploma & 9 & 9.38 \\
\hline & $\mathrm{S} 1$ & 18 & 18.75 \\
\hline & $\mathrm{S} 2$ & 1 & 1.04 \\
\hline \multirow[t]{2}{*}{ Religion } & Islam & 91 & 94.79 \\
\hline & Catholic & 5 & 5.21 \\
\hline \multirow[t]{6}{*}{ Total of Child } & o & 9 & 9.38 \\
\hline & 1 & 28 & 29.17 \\
\hline & 2 & 36 & 37.50 \\
\hline & 3 & 17 & $17 \cdot 71$ \\
\hline & 4 & 5 & 5.21 \\
\hline & 5 & 1 & 1.04 \\
\hline \multirow[t]{3}{*}{$\begin{array}{l}\text { First Age } \\
\text { marriage }\end{array}$} & $<20$ year & 14 & 14.58 \\
\hline & $20-35$ year & 82 & 85.42 \\
\hline & $>35$ year & o & 0.00 \\
\hline \multirow[t]{2}{*}{ Income } & $<\mathrm{UMR}$ & 43 & 44.79 \\
\hline & > UMR & 53 & 55.21 \\
\hline
\end{tabular}

Table 2 shows that of the 96 subjects research that most do not perform pap smears (66.67\%), while on the subject ever checks the majority of checks as much as $1 \mathrm{x}$ and $2 x(14.58 \%)$.
Table 2. Behavior pap smear

\begin{tabular}{lcc}
\hline Pap smear examination & n & \% \\
\hline Never & 64 & 66.67 \\
A total ever done: & & \\
$1 \mathrm{x}$ & 14 & 14.58 \\
$2 \mathrm{x}$ & 14 & 14.58 \\
$3 \mathrm{x}$ & 1 & 1.04 \\
$4 \mathrm{x}$ & 1 & 1.04 \\
$5 \mathrm{x}$ & 1 & 1.04 \\
$6 \mathrm{x}$ & 1 & 1.04 \\
Total & & 100 \\
\hline
\end{tabular}

Table 3. Intention, attitudes, perception behavior control

\begin{tabular}{llccc}
\hline Variables & Category & $\mathbf{n}$ & $\mathbf{\%}$ & $\begin{array}{c}\text { Total } \\
\text { Percent }\end{array}$ \\
\hline Intention & Low & 43 & 44.79 & 100 \\
& High & 53 & 55.21 & \\
Attitude & Negative & 45 & 46.88 & 100 \\
& Positive & 51 & 53.13 & \\
$\begin{array}{l}\text { Subjective } \\
\text { Norm }\end{array}$ & Low & 40 & 41.67 & 100 \\
& High & 56 & 58.33 & \\
$\begin{array}{l}\text { Perception } \\
\text { of control } \\
\text { Behavior }\end{array}$ & Low & 42 & 43.75 & \\
\hline
\end{tabular}

Based on Table 3 showed that the study subjects had the intent was lower by $44.79 \%$ and $55.21 \%$ higher intentions. The negative attitude of $46.88 \%$ and a positive attitude amounted to $53.13 \%$. Subjective norm was lower by $41.67 \%$ and a high of $58.3 \%$. Perception of behavioral control was lower by $43.75 \%$ and $56.25 \%$ lower.

The subject who had conducted the examination was 32 women who never amount of 64 women. Most respondents possessed high intention, a positive attitude, subjective 
Journal of Health Promotion and Behavior (2016), 1(1): 1-8

https://doi.org/10.26911/thejhpb.2016.01.01.01

norm high and high behavioral control perceptions.

Table 4. Results path analysis with STATA program 13

\begin{tabular}{|c|c|c|c|c|}
\hline \multirow{2}{*}{$\begin{array}{c}\text { Variables } \\
\text { Correlation }\end{array}$} & \multirow{2}{*}{$\begin{array}{l}\text { Track } \\
\text { Coef. }\end{array}$} & \multicolumn{2}{|c|}{$95 \%$ CI } & \multirow[b]{2}{*}{ p value } \\
\hline & & $\begin{array}{l}\text { Upper } \\
\text { limit }\end{array}$ & $\begin{array}{l}\text { Lower } \\
\text { limit }\end{array}$ & \\
\hline $\begin{array}{l}\text { Direct Ef- } \\
\text { fect } \\
\text { Pap } \\
\text { Smear }\end{array}$ & 4 & 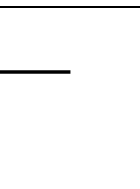 & & \\
\hline $\begin{array}{l}\text { Intention } \\
\text { Perception } \\
\text { of control } \\
\text { behavior } \\
\text { Indirect } \\
\text { Effect } \\
\text { Intention }\end{array}$ & $\begin{array}{l}2.78 \\
1.65\end{array}$ & $\begin{array}{l}4.22 \\
2.58\end{array}$ & $\begin{array}{l}1.48 \\
2.90\end{array}$ & $\begin{array}{l}<0.001 \\
0.010\end{array}$ \\
\hline $\begin{array}{l}\text { Attitude } \\
\text { Norm }\end{array}$ & 2.16 & 2.12 & 0.09 & $<0.001$ \\
\hline Subjective & 1.17 & 2.09 & 0.07 & 0.036 \\
\hline $\begin{array}{l}\text { Perception } \\
\text { of Control } \\
\text { Behavior }\end{array}$ & 1.19 & 3.94 & 1.08 & 0.034 \\
\hline
\end{tabular}

In table 4 shows the results of calculations uses SPSS software STATA 13 obtained coefficient $\mathrm{b}$ between intention with the pap smear is positive in the amount of 2.78 with $\mathrm{p}$ value was $<0.001$ was significant. $\mathrm{B}$ coefficient values between the perception of behavioral control with a pap smear is positive in the amount of 2.65 with ap value is 0.010 was significant. B coefficient values between attitude and intention is positive in the amount of 2.16 with $p$ value of 0.001 was significant. B coefficient values between subjective norms with the intention of positive value that is equal to 1.17 with a p-value was o.036 was significant. B coefficient values between the perception of control behavior with the intention of positive value that is equal to 1.19 with a p-value is $0.034<0.05$ was significant.

\section{DISCUSSION \\ 1. Relationship between the direct and indirect use of Pap smears based on planned behavior theory}

Results of the analysis showed that planned of behavior theory can be used in prediction in use of Pap smears. Variable intentions can directly influence the behavior of a Pap smear while variable attitudes, subjective norms and behavioral control perception have an influence indirectly through intention.

These research findings confirm the theory of planned behavior theory or the theory of planned behavior. The theory of planned behavior is a theory in which the action/ treatment of an individual based on the reason. The central factor in the theory of planned behavior is the intention/ the intention of the individual to perform the behavior.

Theory of planned behavior has three conceptual in the formation of intentions, namely: attitude, subjective norm, and perception of behavioral control (Ajzen, 1991).

The findings of this study support previous research that has been done by Adi and Jennings. Based on the research of Adi on in 2011 in Banyumas stated that the attitude and subjective norm jointly proven to affect the intentions variable inspection early detection of cervical cancer. Relations attitude with the intention of women with $\mathrm{p}<0.001$. The relationship between subjective norms and intention of doing pap smear woman with $\mathrm{p}<0.001$

Research conducted by Jennings (1977) on African American women and Latina showed that there indirectly through intent- 
ion as the dependent variable between attitude, subjective norm, and perception of behavioral control through intention. Results of the analysis showed that there is an indirect effect between attitude and intention with $\mathrm{p}<0.001$, there is an indirect relationship between subjective norms through intention, with $\mathrm{p}<0.001$. There is no direct correlation between the perception of control behavior through intention, with $\mathrm{p}=0.001$.

2. The Relationship is Directly between the Intentions of Using Pap smear with Pap smear Usage Behavior

In the analysis we found that the intention to have a direct influence on the behavior of Pap smear examination is positive. The influence of intention with the Pap smear is obtained regression coefficient $b$ at 2.78 with a p-value was $<0.001$ was significant.

\section{There is a Relationship between Attitudes and Behavior Pap smear Indirectly through Faith}

In the analysis we find that attitude has an indirect relationship with the Pap smear through intent with coefficient $b$ between attitudes with the intention of positive value that is equal to 2.16 . The p-value was $<0.001$ and was significant.

Attitudes toward the behavior refer to the extent to which a person's vote has the advantages and disadvantages of such behavior. Individuals will form a belief about an object to be assessed positively or negatively (Ajzen, 1991). Attitude will bring influence a decision-making process that is thorough and reasoned (Fishbein \& Ajzen, 1975).

The more people have a judgment that a behavior will produce positive consequences then the individual will tend to be positive towards such behavior; conversely, the more people have a judgment that a behavior will result in negative consequences, the individual will tend to be negative towards the behavior (Ajzen, 2005).

The findings of this study support previous studies that have been done. Research conducted by Adi in Banyumas in 2011 showed that there is a relationship between attitude and intention examination early detection of cervical cancer. Relations attitude with the intention of women with $\mathrm{p}<0.001$ with 0.486 closeness value which shows that attitudes and intentions smears have a meaningful relationship.

Jennings (1977) on African American women and Latina obtained that showed that there is an indirect effect between attitude and intention with the $\mathrm{p}$ value of $<0.001$. Research conducted by Wahyuni in 2013 in the district Ngampel, Kendal showed that there is a relationship between attitudes and behavior with the behavior of early cancer detection servisk with $\mathrm{p}=0.043$ and the value of the odds ratio of 2.19.

\section{There is a relationship between subjective norms of behavior Pap smear indirectly through faith in Sewon 1 Public Health}

In the analysis we found that subjective norms influence indirectly through a Pap smear is positive intention in the amount of 1.17 with ap value of 0.036 and was significant.

According to Fishbein and Ajzen (1975) suggests that subjective norm is a function that was based on the belief that called normative beliefs, that is the belief of agreement or disagreement regarding the person or group that is important for the individual to a behavior (salient referent beliefs). Subjective norm allows one to determine in advance how the actions will be judged by oth- 
Journal of Health Promotion and Behavior (2016), 1(1): 1-8

https://doi.org/10.26911/thejhpb.2016.01.01.01

ers, and the norm is kriterian for others to support or reject the person's behavior (Noorkasiani, 2012).

Behavior formed in one of two main factors, namely the stimulus and response). Where in the stimulus is a factor from outside oneself (external factors), and the response is a factor of the person (internal factors).

Social support in women of childbearing age can be sourced from partner, family, friends and health professionals (Gustiana et al., 2014). Family is predisposes individual factors on the utilization of health services. The family does not directly influence the utilization of health care services, but as a motivating factor to cause the intention to utilize health services (Andersen (1968) in Muzamham, 2007).

The more people perceive that the reference social recommended to perform a behavior then the individual will tend to feel social pressure to perform the behavior, on the contrary the people perceive that the reference social recommends not perform a behavior then the individual will tend to feel the social pressure not to perform the behavior (Ajzen, 2005).

The findings of this study support previous studies that have been done. Research conducted by Linadi on EFA in Ivory Semarang Housing Pucang obtained relationship between husband support the pap smear with a value of $p=0.001$. Research conducted by Wahyuni in 2013 in the district Ngampel Kendal showed that there is a relationship between husband support the behavior with the behavior of early cancer detection servisk with $\mathrm{p}=0.010$ and the value of the odds ratio of 2.19.
Research conducted by Adi in Banyumas district in 2011 showed that there is a relationship between subjective norm and intention women in pap smear with $\mathrm{p}<0.001$ with the value of the closeness of 0.788 which indicates a strong relationship between subjective norms and intentions of women in the early detection ca cervix.

Research conducted by Jennings (1977) on African American women and Latina obtained that showed that there is an indirect effect of subjective norm with the intention to $\mathrm{p}$ value of $<0.001$.

Research conducted by Gustiana, et.al 2014 showed that there is a relationship of social support cervical cancer prevention behavior, with $\mathrm{p}<0.001$. Of the value of the odds ratio can be concluded that the respondents have a good chance to do a social support do good prevention behaviors 9:59 times compared to respondents who have poor social support.

5. There is a Relationship between the Perception of Control Behavior with the Behavior of Pap smear Directly and Indirectly through Faith in Puskesmas Sewon 1

In the analysis we found that the perception of behavioral control has a direct influence on the Pap smear is positive in the amount of 2.65 with ap value is 0.010 was significant and perceptions of control behavior has an influence indirectly through intention Pap smear with a positive value of 1.19 with value p equal to 0.034 was significant.

Perceived behavioral control is the belief of the individual against the supporting or inhibiting factor to perform a behavior (Ajzen, 2005). Factors ability is one predisposes in the behavior of individuals in the use of health services. The ability comes from a family (such as income and savings, 
health insurance or other sources other sources) and the community (e.g, availability of facilities and health care personnel, length of wait for service, and the time used to reach the service facilities of the (Aderson (1968) in Muzaham, 2007).

Constraint is one factor in the behavior of individuals in the use of health services. Obstacles are the things that prevent people who have been motivated to make health behavior. Constraints can be either internal such as lack of knowledge about healthy behaviors or fears to perform certain actions and externally due to a lack of resources such as money, time and doctors are required (Antonovsky and Kats (1970) in Muzamham, 2007).

Confidence in yourself and trust in public figures who believed in providing information or motivation in health care, ease in the sense that service is within easy reach, and the social economy in terms of costs incurred for the service cost will influence the decision to seek or use such services (Emilia, 2008).

The more people feel a lot of supporting factors and little obstacle to be able to do a behavior, then people will tend to perceive themselves easily to such behavior; conversely, the less people feel a lot of factors supporting and inhibiting factors for can perform a behavior, then people will tend to perceive they difficult to perform the behavior (Ajzen, 2005). Control behavior can directly affect the behavior, the greater the perception of behavioral control the more powerful individual intention to perform the behavior (Ajzen, 1991).

The findings of this research, supporting research conducted by Jennings (1977) on African American women and Latina ob- tained that showed that there was no direct influence between the perception of control behavior with intent to $\mathrm{p}$ value of $<0.001$.

The conclusion of this study, there is a relationship of direct and indirect use of Pap smears by planned of behavior theory. There is a direct relationship between the intention to conduct a Pap smear (the value of coefficient $b=2.78 ; \mathrm{p}<0.001$ ), an indirect relationship between attitudes and behavior of Pap smears (the value of coefficient $b=2.16$; $\mathrm{p}<0.001$ ), an indirect relationship between subjective norms of behavior Pap smear (the value of coefficient $b=1.17 ; p=0.036$ ), a direct correlation (coefficient value $b=2.65$; $\mathrm{p}=0.000$ ) and not directly between the perception of control behavior with Pap smear behavior (the value of coefficient $\mathrm{b}=1.19 ; \mathrm{p}=$ 0.034).

Suggestions for further research are expected to further investigate the direct relationship and not direct behavior based Pap smear planned of behavior by adding a variable in the formation of attitudes that behavior beliefs and outcome evaluation, subjective norm variable formation which is normative beliefs and motivation to comply, the variable formation of perception of control is control beliefs and perceived power behavior and can include elements of social and cultural variables.

\section{REFERENCE}

American Cancer Society (2014). Cervical Cancer Prevention and Early Detection.

Ajzen I (1991). The Theory of Planned Behavior. University of Massachusetts at Amherst: Academic Press. Inc.

Aziz A (2004). Socio- Economic Determiants of Pap Screening Among Married Women in Peninsular Malaysia. Interna- 
Journal of Health Promotion and Behavior (2016), 1(1): 1-8

https://doi.org/10.26911/thejhpb.2016.01.01.01

tional Journal of Humanities and Social Science 3 (3).

Adi TN (2011). Women and Cervical Cancer Early Detection (Studies Correlations between Attitudes and Subjective Norms with the intension of Adult Women in the Early Detection of Cervical Cancer Examination). A diurn Acta 7 (2).

Ajzen I (2005). Attitudes, Personality, and Behavior (2nd ed). Berkshire: Open University Press.

Directorate for Control of Communicable Disease (2009). Handbook Prevention of Cervical Cancer and Breast Cancer. Jakarta: Ministry of Health.

Emilia O (2008). Health Promotion in the scope of Reproductive Health. Yogyakarta: Pustaka Press.

Fishbein M, Ajzen I (1975). Belief, Attitude, Intention, and Behavior: An Introducetion to theory and research. Philippines: Addison- Wesley Publishing Company.

Fishbein M, Ajzen I (1980). Understanding Attitudes And Predicting Social Behavior. New Jersey: Prentice Hall Engelwood Cliffs.

Fishbein M, Ajzen I (2010). Predicting And Changing Behavior: The reasoned action approach. New York: Psychology Press.

Gustiana D (2014). Factors Associated with Cervical Cancer Prevention Behavior in Women of fertile age. Jom PSIK 1 (2).
Jennings KM (1977). Predicting intention to Obtain a pap smear Among African american and latina women. A Bell \& Howell Information Company. 300 North Zeeb Road, Ann Arbor MI 48106-1346 USA.

Ministry of Health (2015). Health in the Framework of Sustainable Development Goals (SDGs). Jakarta: Ministry of Health RI.

Kusmiran E (2011). Adolescent Reproductive Health and Women. Jakarata: Salemba Medika.

Lestadi J (2009). Cytology Pap Smear Tool Prevention and Early Detection of Cervical Cancer. EGC: Jakarta.

Linadi KE (2013). Support Husband Encourages Participation Pap Smear pair fertile age (pus) in Ivory Pucang Housing Semarang. Journal of Reproductive Health 4 (2): 61-71.

Manuaba IAC, Manuaba, IBGF, Manuaba IBG (2009). Understanding Women's Reproductive Health. Jakarta: EGC.

Mehta V, Vasanth V, Balachandran (2009). Pap smear. Indian J Dermatol Venereol Leprol 75: 214-6.

Muzaham F (2007). Sociology of Health. Jakarta: UI University.

Noorkasiani, Krisanty P, Sumartini M (2002). Sociology Midwifery. Jakarta: Trans Media Info.

Samadi H (2010). Cervical cancer. Jakarta. 